\title{
CORRESPONDENCE
}

\section{Cashing in}

SIR - In Nature of 28 May (p.260), De Witt Stetten Jr writes concerning the release of the gene of Veniality and the epidemic produced thereby. Enjoying as he does a healthy income as an author of one of the best biochemical textbooks around, but being precluded from participating in the gene technology largesse by virtue of his employment as a civil servant, Dr Stetten makes a witty but not inaccurate statement as to the consequences of the new commercial value to gene technology in terms of suppressing the totally free exchange of information which was, for many years, characteristic of biomedical research. However, in order to establish a risk/benefit ratio, someplace along the line the benefit must also be mentioned; it is not just that the socioeconomic status of the upwardly mobile scientist in gene technology is improved (important though that may be!), but there is reason to expect a profound acceleration of scientific development for human use to occur.

A number of foundations have been predicated on the clear and demonstrable proposition that the rate of transformation and transport of information from the laboratory bench to the clinical bedside is extremely slow and tends to fall outside the purview of the grant support system developed over the years by the National Institutes of Health. Venture-capital supported gene technology is certainly one example (together with hybridoma technology and other forms of research and development partnerships) wherein a much more rapid translation of laboratory discoveries to the benefit of human consumers can be accomplished. It is in the context of this benefit that the risk to scientific communication should be evaluated. $\mathrm{I}$, for one, would rather see the scientist "make a buck" than be excluded from that process by non-scientific entrepreneurs!

Virginia Mason Research Center,

JoHN C. HouCK Seattle, Washington, USA

\section{Known quantity}

SiR - Semi-log notation, as advocated by J.A. Nicoll (Nature 10 June, p.450), is already known, see Danloux-Dumesnils, M., The Metric System, 152 (Athlone, London, 1969).

Leeds, UK

Oliver Mil.burn

\section{Earth science in Ovid}

SIR - Two passages in Ovid's Metamorphoses should be of interest to geologists for the way they illustrate some early ideas that without too much exaggeration could be epeirogenic, geomorphic and vulcanologic. The first passage occurs in a long philosophical peroration delivered by Euphorbus of Samos; the sccond in a song by one of the Aonian sisters, all of whom were too vainglorious for their own good.

Euphorbus declaims ${ }^{1}$ :

Nothing, I fecl sure, lasts long under the samc appearance ... thus often has the condition of places changed. I myself have scen what once was solid land changed into sea; and again I have seen land made from the sea. Sea shclls have been seen lying far from the ocean, and an ancient anchor has been found on a mountain top. What was once a level plain, down-flowing waters have made into a valley; and hills by the force of floods have bcen washed into the sea . Zancle also is said to have been a part of Italy until the sea washed away their common boundary and thrust back the land by the intervening waters. If you seek for Helice and Buris, once cities of Achaia, you will find them beneath the waves; and the sailors still show you the sloping citics with their buried walls.

Calliope, the Aonian - with harp and song to Ceres ${ }^{2}$ :

The huge island of Sicily had been heaped upon the body of the giant, and with its vast weight was resting on Typhoeus ... He struggles indeed, and strives often to rise again . . . and Aetna's weight is on his head. Flung on his back beneath this mountain, the fierce Typhoeus spouts forth ashes and vomits flames from his mouth. Often he puts forth all his strength to push off the weight of the Earth and to roll the cities and the great mountains from his body: then the Earth quakes, and even the king of the silent land is afraid lest the crust of the Earth split open in wide seams. .

M. KAMEN-KAYE

\section{Cambridge,}

Massachusetts, USA

1. Miller, F.J. (transl.) Ovid in six volumes, III Metumorphoses 3td edn, I, 263 (Harsard Liniversity Press. 1977).

2. ibid. II. $383 ; 385$

\section{Vietnam now}

SIR - Large numbers of individuals in IndoChina, both military and civilian, were inadvertently exposed to dioxin (TCDD; 2,3,7,8-tetrachlorodibenzo-para-dioxin) as a result of US actions during the Second Indo-China War. This continues to be a matter of grave concern owing to the toxic, teratogenic, carcinogenic, and mutagenic properties of this substance. I provide the following information on dioxin levels in Vietnam owing to the widely divergent values that keep appearing especially in the popular and semi-popular literature, often incorrectly attributed to me.

Dioxin was disseminated as an impurity of the 2,4,5-T (2,4,5-trichlorophenoxyacetic acid) component of the now notorious anti-plant chemical weapon code-named Agent Orange; and also of its much more modestly used close relatives (Agent Orange II, Pink, Purple, and Green), all subsumed here under Agent Orange. The Agent Orange was dispensed by the United States between 1962 and 1970 (primarily during 1966-70) in attacking inland and coastal forests and some crop lands. Although Kampuchea, Laos ${ }^{3}$, and North Vietnam were all thus attacked, it was South Vietnam that was the major recipient ${ }^{4}$.

Approximately $44,300 \mathrm{~m}^{3}$ (57.0 million $\mathrm{kg}$ ) of Agent Orange was expended by the United States during the war, containing about 24.1 million $\mathrm{kg}$ of $2,4,5-\mathrm{T}$ per se (ref. $1 \mathrm{p} .26$ ). It is difficult to make a reliable estimate of the actual amounts of dioxin contained in the Agent Orange used in Indo-China owing to the untimely destruction by the US Air Force and the Dow Chemical Company of the reference samples of most of the lots used. An estimate based on Dow determinations released by the US Air Force in 1974 is that the Agent Orange had an average dioxin content of $2.5 \mathrm{~g} \mathrm{~m}^{-3}$, or $1.9 \mathrm{mg} \mathrm{kg}^{-1}$ (ref. $1 \mathrm{pp} .44-45$ ). This suggests that a total of at least $110 \mathrm{~kg}$ of dioxin was disseminated. Some new information released by the US Air Force in 1980 indicates that the total was somewhat higher, perhaps $170 \mathrm{~kg}$

(ref. 5: p.368). As dubitable as these Dow/Air Force data are, I am aware of no others from which to make better estimates. It should also be noted that the total amount of dioxin in Vietnam, whatever it was, was probably augmented to a slight extent as a result of the burning of wood that had been sprayed with 2,4,5-T.

It appears that approximately half the amount of aerially applied dioxin decomposes within a few days, with the remainder becoming more permanently incorporated into the soil and biota. Here it can work its way up food chains, including those culminating in humans, becoming concentrated in the process. The dioxin thus incorporated into the ecosystem appears to disappear following first-order kinetics, having an environmental half life of perhaps 3.5 years (refs. 4,5 ). In the case of Vietnam, if one makes the simplifying assumptions that the amount of dioxin introduced was, indeed, $170 \mathrm{~kg}$ and that it had all been introduced in 1968, then perhaps $8 \mathrm{~kg}$ remained in $1980,3 \mathrm{~kg}$ will be present in 1985 , and $1 \mathrm{~kg}$ in 1990 . Its legacy, on the other hand, could persist far longer.

Arthur H. Westing

Hampshire College,

Amherst, Massachusetts, USA

1. Westing, A. H. Ecological Consequences of the Second IndoChina War. (Almqvist and Wiksell, Stockholm,1976.)

2. Westing, A. H. in Harvest of Death, 177-205 (Macmillan Free Press, New York, 1982).

3. Westing, A. H. Nature 294, 606 (1981).

4. Westing, A. H. Ecol. Bull. 27, 285-294 (1978)

5. Westing, A. H. SIPRI Yearbook (1982)

\section{Too many drugs?}

SIR - In Nature of 1 April, M. Weatherall' reviews the reasons for the fall off in the number of newly introduced drugs using the now familiar arguments of restrictive

legislation with its inappropriate toxicity screening procedures and the need to explain to the public the problems involved in solving the risk-to-benefit equation, recently widely discussed both nationally and multinationally ${ }^{2-4}$.

The pharmaceutical industry accepts ${ }^{5}$ that its future contribution to treating the generally recognized pattern of Western diseases will be minimal, a view substantiated by the US Senate report ${ }^{6}$ linking six of the ten major diseases to dietary imbalance, epidemiological evidence $^{7}$ that repeatedly points to ways of preventing some important cancers, obesity and heart disease, and Hellman's assertion that there will be no magic bullet in the chemotherapy of cancers ${ }^{8}$. In spite of this last statement recent proposals have been placed before the Committee for the Safety of Medicines to introduce a special classification for new experimental molecules which may be potential anticancer drugs. These proposals, if accepted, will allow the clinical trial of molecules, designed using current biochemical knowledge and that possess, theoretically at least, the possibility of interfering with cancer

Continued on page 210 


\section{Continued from page 114}

cells to be tested in humans without the whole range of present toxicity study requirements. This may perhaps be part of Weatherall's "unattractive message that the experts must tell the public" and does fall into the category of "desperate remedies for desperate ills": it has also served to reactivate industrial interest in this therapeutic area.

An even more delicate area was not discussed. Proposals ${ }^{9}$ for attaining a population of whom 95 per cent may use synthetic mood-modifying drugs regularly by the 1990s may be becoming more tangible with the latest developments in our biochemical understanding of the already overprescribed 1,4-benzodiazepines: identification ${ }^{10}$ of a specific receptor for them, modifications of the endogenous ligand(s) ${ }^{11}$ of the benzodiazepines and the subclassification of those receptors 13 with their own agonist/antagonist complement such as the type I-selective triazolopyridazines, 14 exposes a whole new area for exploitation into social psychotropic drugs. The experts ought to be talking about some of these aspects also, accepting Sakharov's charge 15 that we the scientists should take responsibility for the applications of science and technology to life.

Shoscombe, nr Bath, UK

\section{UPTON}

1. W'atherall, M. Nature 29, 387 (1982).

2. Teeling-Smith, G. A Question of Balance (Office of Healith Economics, L ondon, 1980).

3. Feldmann, E.G. J. pharm. Sci. 69, 2 (1980)

4. Brimblecombe, R.W'. Trends pharm. Sci. 21 , (1981).

5. Pagct, G.E. in Medicines for the Year 2000 (eds Teeling Smith, (i. \& Wells. N.) 148 (Otfice of Health Economics, l.undon, 1979).

6. Dietary Goals for the United States (The Scicct Committec on Nutrition and Human Necds, US Government, 1978).

7. Hiat, H. et. al. in Origins of Human Cancers (Cold Spring Harbor L.aboratorics, New York, 1977).

8. Hellman, K. Pharm. J., 600 (1981).

9. Teeling-Smith, G. in Medicines in the 1990s, 14 fOffice of Health Economics, L.ondon, 1979).

10. Squires, R.F. \& Bracstrup, C. Nature 266. 732 (1977).

11. Martin L. Trends Neurowi, 3, 299 (1980).

1. Martin, L.L. Trends Neurond. 3, 299 (1980).

13. Klepner, C.A. et al. Pharm. biochem. Behav. 11, 457 (1979)

14. Bracstrup. C. Trends Neurosci. 3, 301 (1980)

15. Sahharon. A. Nature 291, 184 (1981)

\section{Return of malaria}

SIR - Chapin and Wasserstrom' suggest that resurgence of malaria in Central America and India was the result of introduction of high yiclding varieties (HYV) of rice and cotton. Wc feel that this conclusion is incorrect and that the basic data used by Chapin and Wasserstrom were defective. What follows is our vicw of how malarial resurgence came about in India.

(1) During the years of resurgence cotton production remained at a roughly constant level. There was a marginal increase in rice production but the area under HYV was low. Use of DDT in 1960-64 was 73,313 tonnes in public health as against 3,000 tonnes in the agricultural sector (see table). Even in subsequent years, use of DDT in agriculture was far less than for public health. However, it may also be pointed out that malathion insecticide has been in continuous use in agriculture since 1958 and malaria vectors have remained susceptible to it wherever it has not been used by the National Malaria Eradication Programme (NMEP). It was used in Gujarat to control DDT and $\mathrm{HCH}$ resistan Anopheles culicifacies and between 1970 and 1973, susceptible $A$. culicifacies developed 4-fold resistance 2 .

(2) The origins of the setback to the Indian anti-malaria programme can be traced to 1963 when approximately 2 million of the population werc involved in scattered focal outbreaks in the consolidation phase. Focal outbreaks during subsequent years became more serious. In areas which could not be tackled an estimated population of 12,17 and 32 million respectively were temporarily reverted to attack phase during 1965,1966 and 1967. During 1968, out of a total of 393.25 units, 71.385 units involving a population of 91 million were reverted to spraying, 51.785 from the consolidation and 19.60 from the maintenance phase. In addition, there were 41.60 units under NMEP which never moved out of the attack phase. These units were located in hyperendemic areas of 20 states, union territories and the coalfields ${ }^{3,4}$.

(3) Whilst the incidence of malaria in rural areas went down, there was a resurgence in the cities of India. In Tamil Nadu in 1963, 95 per cent of the cases came from urban areas. In 1964-67 urban malaria constituted 80 per cent of the problem, and malaria was found to be diffusing towards the rural areas ${ }^{5} . A$. stephensi, the urban malaria vector, was found to be resistant to DDT and $\mathbf{H C H}$.

(4) There are 7 major vectors of malaria in India. Insecticide resistance has been detected in Anopheles culicifacies and $A$. stephensi with isolated reports in $A$. fluviatilis ${ }^{6,7}$. The first report of increased tolerance in $A$. stephensi came from Erode, Tamil Nadu in $1956^{8}$ and that in $A$. culicifacies from Gujarat in $1957^{9}$ Between 1959 and 1967 DDT resistance in $A$. stephensi and A. culicifacies became widespread. During 1967-69 there were 96 units under persistent attack phase and malaria incidence increased in 56 units. In 44 units tested, $A$. culicifacies was found resistant to DDT in 35 units and to DDT $+\mathrm{HCH}$ in 5 units. $A$. stephensi was also tested against DDT in 8 units and was found to be resistant in four ( ref. 10). In fact withdrawal of spraying has been reported to have resulted in reversion towards susceptibility. Thus resistance was the result of spraying under NMEP and it preceded the introduction of HYV in India.

We believe that resurgence of malaria in India was largely due to administrative, social, economic and financial reasons ${ }^{11}$, and its diffusion was facilitated by the widespread occurrence of the parasite and anophelism in the country. The resistant populations of these mosquitoes found additional breeding grounds due to development activities. In order to stabilize and increase agricultural production, the gross area under irrigation was increased from 29.05 million hectares in 1960-61 to 37.10 in $1968-69$, steadily rising to 57.02 million hectares in 1979-8012. Similarly, unplanned growth in urban and rural housing and lack of adequate water disposal facilities made the surroundings more mosquitogenic and receptive to malaria. Large areas of the country (such as the Punjab) which in the past were prone to malaria epidemics in years of high precipitation turned endemic. Irrigation increased the average humidity of the atmosphere and made the regions more conducive for mosquitoes' survival. This had the most profound affect on the basic reproduction rate. Thus there was a resurgence of malaria in areas of the country at one time freed from the disease.

Malaria Research Centre (ICMR), V. P. SHARMA Delhi, India

K. N. Mehrotra Indian Agricultural Research Institute, New Delhi, India

1. Chapin, G. \& Wasserstrom, S. Nature 293, $181-185$ (1981) 2. Rajagopal, R. Ind. J. med. Res. 66, 27-28 (1977).

3. Madhok, R. N. Report of the special committee to review the working of the NMEP (1967).

4. Dhir, S. L. Bull. Ind. Soc. Mal. Com. Dis. 5, 16-27 (1968).

5. Roy, R. G., Panchepakesan, A., Sitaraman, N. L.. Ganesan, A. V. \& Ghosh, R. B. Ind. J. med. Sci. 30. $313.316(1976)$

6. Raphavan, N. G. S. el al. Bull. Ind. Soc. Mal, Com. Dis. 4 209-245 (1967).

7. WHO Tech. Rep. Ser. No. 585 (1976).

8. Rajagopalan, N., Vedamanikkam, J. C. \& Ramoo, H. C. Bull. Nat. Soc. Ind. Mal. Mosq. Dis. 4, 126-128 (1956).

9. Rahman, J., Rov, M. L. \& Singh, K. Ind. J. Malar. 13. 125.130 (1959).

10. Rao, T. R. Report of the Evaluation In-Depth of the NMEP of India (1970).

11. Off. Rec. W'ld HIth. Org. 176, 106-124 (1969).

12. Report of the working group on minor irrigation for formulation of the VI Plan proposals for the years 1980-85. Minor Irrization Division, Ministry of Agricullure, p. 7 ((iovernment of India, 1980).

\begin{tabular}{|c|c|c|c|c|c|c|c|c|c|c|c|c|c|c|c|}
\hline \multicolumn{16}{|c|}{ Incidence of malaria, DDT used and agricultural production in India } \\
\hline & 1960 & 1965 & 1966 & 1967 & 1968 & 1969 & 1970 & 1971 & 1972 & 1973 & 1974 & 1975 & 1976 & 1977 & 1978 \\
\hline $\begin{array}{l}\text { Malaria incidence } \\
\text { (millions) }\end{array}$ & - & 0.10 & 0.15 & 0.28 & 0.27 & 0.35 & 0.69 & 1.31 & 1.43 & 1.93 & 3.17 & 5.16 & 6.46 & 4.74 & 4.14 \\
\hline $\begin{array}{l}\text { DDT (tech) used in public } \\
\text { health (tonnes) }\end{array}$ & 21,007 & 6,671 & 2,762 & 3,045 & 5,821 & 6,401 & 6,205 & 7,350 & 7,034 & 6,821 & 6,700 & 7,250 & 7,250 & 9,051 & 6,800 \\
\hline $\begin{array}{l}\text { DDT (tech) used in } \\
\text { agriculture (tonnes) }\end{array}$ & 600 & 2,400 & 2,400 & 2,400 & 2,400 & 2,400 & 2,400 & 2,400 & 2,400 & 2,880 & 2,934 & 2,450 & 3,000 & 2,450 & 4,720 \\
\hline $\begin{array}{l}\text { Rice production } \\
\text { (million tonnes) }\end{array}$ & 34.50 & 30.59 & 30.44 & 37.61 & 39.61 & 40.43 & 42.23 & 43.07 & 39.25 & 44.05 & 39.58 & 48.74 & 44.91 & 52.67 & 53.77 \\
\hline $\begin{array}{l}\text { Area under rice in million } \\
\text { hectares (in parentheses, } \\
\text { under HYV) }\end{array}$ & $\begin{array}{l}34.1 \\
(0)\end{array}$ & $\begin{array}{c}35.5 \\
(0)\end{array}$ & $\begin{array}{l}35.3 \\
(0.9)\end{array}$ & $\begin{array}{l}35.4 \\
(1.8)\end{array}$ & $\begin{array}{l}37.0 \\
(2.7)\end{array}$ & $\begin{array}{l}37.6 \\
(4.3)\end{array}$ & $\begin{array}{l}37.6 \\
(5.6)\end{array}$ & $\begin{array}{l}37.8 \\
(7.4)\end{array}$ & $\begin{array}{l}36.7 \\
(8.2)\end{array}$ & $\begin{array}{c}38.3 \\
(10.0)\end{array}$ & $\begin{array}{c}37.9 \\
(11.2)\end{array}$ & $\begin{array}{c}39.5 \\
(12.4)\end{array}$ & $\begin{array}{c}38.5 \\
(13.3)\end{array}$ & $\begin{array}{c}40.3 \\
(16.1)\end{array}$ & $\begin{array}{l}40.5 \\
(16.9)\end{array}$ \\
\hline $\begin{array}{l}\text { Cotton production } \\
\text { (million bales) }\end{array}$ & 5.60 & 4.85 & 5.27 & 5.78 & 5.45 & 5.56 & 4.76 & 6.95 & 5.74 & 6.31 & 7.16 & 5.95 & 5.84 & 7.24 & 7.96 \\
\hline
\end{tabular}

